\title{
Special issue on coal geology in China
}

\author{
Yuegang Tang ${ }^{1}$
}

Published online: 29 June 2020

(C) The Author(s) 2020

China remains the largest producer and consumer of coal in the world. The proportion of coal in the diversified Chinese energy structure has been declining gradually year by year, but the characteristics of China's energy resources and development status indicate that the dominant position of coal in primary energy production and consumption would not change for a long period time. Coal is still the main energy source in China and will likely remain in the foreseeable future. Coal, as the main energy source, has promoted the development of the Chinese economy. However, the extensive use of coal has also resulted in a range of environmental issues. Coal production and consumption in China are facing many problems of science and engineering in coal geological exploration, coal mining, coal processing, coal conversion, coal utilization, and ecology in coal. This special issue brings together experts on almost every aspect of coal petrology and chemistry, organic geochemistry of coal, coal sedimentology, structural geology of coalfield, clean coal geology, coal remote geology, and coal geological information technology. Dai and Finkelman (2019) had organized scholars to publish papers in a special issue of the International Geology Review (2018, volume 60, issues (5-6)). It includes reviews on coal products in China, the geologic settings of Chinese coal deposits, the health impacts of coal use in China, valuable elements in Chinese coal, related to the emission of $\mathrm{U}, \mathrm{Hg}$, and other elements during coal combustion, the application of coal combustion products, ash

Yuegang Tang

tyg@vip.163.com

1 College of Geoscience and Surveying Engineering, China University of Mining and Technology (Beijing), Beijing 100083, China and slag from coal gasification in China, stone coal in China, $\mathrm{CO}_{2}$ storage in coal to enhance coalbed methane (CBM) recovery, resource and geology of CBM in China. And they published a book: Coal Geology of China.

In China, five nation-wide coal resource assessments have been carried out since 1949. The first coal resource assessment was carried out by the Ministry of Coal Industry in 1958-1959. The second one was carried out in 1973-1980. The third one was carried out in 1992-1997. Another coal resource assessment led by the Ministry of Geology and Mineral Resources was carried out in 1983-1988. The latest coal resource assessment, which has a formal name of "National Potential Assessment of Coal Resources in China", was led by the Ministry of Land and Resources and conducted by the China National Administration of Coal Geology in collaboration with China University of Mining and Technology (Beijing) in 2007-2012. New data shows China is of the large coal resource countries in the world, with a total of 5.9 trillion tons of shallow coal resources of less than $2000 \mathrm{~m}$ in depth, including 2.02 trillion tons of discovered resources (reserves) and 3.88 trillion predicted resources (Cheng et al. 2016). There are eight major coal-accumulating periods during geological history in China, including the Early Carboniferous, Late Carboniferous-Early Permian, Late Permian, Late Triassic, Early-Middle Jurassic, Early Cretaceous, Paleogene, and Neogene. The Chinese continent has experienced multi-stage tectonic movements since the Late Paleozoic, which resulted in the spatial and temporal heterogeneity of its continental tectonic evolution, and the complexity of its basement properties.

This special issue publishes eight papers related to different issues in the field of coal geology in China. The first to fourth papers are related to a part of the work of the National Potential Evaluation of Coal Resources. The first 
paper introduced the concept of coal occurrence structural units, the structural zoning of coal occurrence, five coal occurrence structural areas, and the distribution of coalcontrolling structural styles (Cao 2018). Based on the analysis of the relationship between the structural characteristics and occurrence of coal in these coalfields, the coalcontrolling structures are divided into six groups of structure style. They are briefly summarized. A first-level belt (the north-south trending Helan-Taihang-Ailao mountains structural belt) and three second-level belts (the Altay-Yin mountains structural belt, the Kunlun-Qinling-Dabie mountains structural belt, and the Greater Khingan-Taihang-Wuling mountains structural belt) control the distribution of Chinese coal resources. Structure study of coalfield is the basic work of coal resource evaluation, exploration, and exploitation.

The second paper summarizes these research achievements on the sequence stratigraphy and coal accumulation of the major coal-accumulation periods. The distribution range of the coal-forming basins, sedimentary facies types, and coal-accumulating models are identified. The sequence stratigraphic frameworks of the major coal-accumulating periods were established. The distribution of thick coals and migration patterns of the coal-accumulating centers in the sequence stratigraphic framework were analyzed. In the third paper, the Early Cretaceous coal-bearing series in the southeastern margin of Songliao Basin are subdivided into five third-order sequences. The major coal seams were developed in sequence II and III. The thick coal seam formed during the relative balance between the increased rate of the accommodation space and the rate of peat accumulation for a longer period.

The fourth paper reviews coal petrology, coal quality, coal metamorphism, and coal geochemistry (Dai et al. 2012, 2020a) in China. Recently some scholars researched graphenic material prepared from anthracites (Huan et al. 2019). The fifth one presented some of the organic geochemical characteristics and depositional environment of bark coal, Chinese special coal type, which is rich in barkinite that has not been recognized by the International Committee for Coal and Organic Petrology (ICCP) (Hower et al. 2007; Tang et al. 2011). In the sixth paper, a new definition of Clean Coal Geology (CCG) is proposed. The research content includes cleaning potential evaluation (Tang et al. 2020), geological guarantee for coal mining, ash yields and sulfur contents (Dai et al. 2020b), trace elements (Ren et al. 1999; Finkelman et al. 2019), pollution caused by coal, and mine reclamation. Although clean coal technology had developed during the 1980-1990 in the USA, the progress of CCG in China was developed briefly and divided and delineated into four stages, which significantly contributed to the development of the Chinese clean coal industry.
With the rapid development of coal geological exploration in China, coal remote sensing technology has evolved from a coal geology-based survey to a comprehensive survey that factors in resources, environment, ecology, and so on. The seventh paper summarizes the general situation, theories, development process, key research, and future of remote sensing technology for coal mining in China. The eighth paper sheds light on the development of coalfield or mining geological and surveying spatial management information systems, which will provide the basic dynamic data guarantee for the online decision-making of the intelligent mining of coal mine (Mao et al. 2018).

Green coal exploration, intelligent mining, clean coal technology, ecologic development is a priority in the China coal industry. Coal geology could play an important role in developing green mining and clean coal utilization. The purpose of editing the special issue is for graduate students and researchers of domestic and abroad coal industry and ecology to make a better understanding of the related development status and tendency as well as existing problems and to facilitate developing advanced techniques for Chinese coal geology in the future.

The editors would like to acknowledge all of the authors who contributed papers to the special issue on coal geology in China. Very thanks are expressed to many academic colleagues who have helped the publication of this special issue by reviewing the manuscripts. I would also like to thank the National Basic Research Program of China (No. 2014CB238905) and the National Natureal Science Foundation of China (Nos. 41572146 and 41872175), which financially supported my travel for discussions on various aspects of the Special Issue.

Open Access This article is licensed under a Creative Commons Attribution 4.0 International License, which permits use, sharing, adaptation, distribution and reproduction in any medium or format, as long as you give appropriate credit to the original author(s) and the source, provide a link to the Creative Commons licence, and indicate if changes were made. The images or other third party material in this article are included in the article's Creative Commons licence, unless indicated otherwise in a credit line to the material. If material is not included in the article's Creative Commons licence and your intended use is not permitted by statutory regulation or exceeds the permitted use, you will need to obtain permission directly from the copyright holder. To view a copy of this licence, visit http://creativecommons. org/licenses/by/4.0/.

\section{References}

Cao DY (2018) Tectonnic framework of coalfields and tectonic control of coal seams in China. Science Press, Bejing (in Chinese)

Cheng AG, Cao DY, Yuan TX (2016) China occurrence regularity of coal resources and resource evaluation. Science Press, Beijing (in Chinese) 
Dai SF, Finkelman RB (2019) Coal geology of China. Taylor and Francis, London

Dai SF, Ren DY, Chou CL, Finkelman RB, Seredin VV, Zhou YP (2012) Geochemistry of trace elements in Chinese coals: a review of abundances, genetic types, impacts on human health, and industrial utilization. Int J Coal Geol 94(3):3-21

Dai SF, Hower JC, Finkelman RB, Graham IT, French D, Ward CR, Eskenazy G, Wei Q, Zhao L (2020a) Organic associations of non-mineral elements in coal: a review. Int $\mathrm{J}$ Coal Geol 218:103347

Dai SF, Bechtel A, Eble CF, Flores RM, French D, Graham IT, Hood MM, Hower JC, Korasidis VA, Moore TA, Püttmann W, Wei Q, Zhao L, O'Keefe JMK (2020b) Recognition of peat depositional environments in coal: a review. Int J Coal Geol 219:103383

Finkelman RB, Dai SF, French D (2019) The importance of minerals in coal as the hosts of chemical elements: a review. Int J Coal Geol 212:103251

Hower JC, Suarez-Ruiz I, Mastalerz M et al (2007) Discussion the investigation of chemical structure of coal macerals via transmitted light FTIR microscopy by X. Sun. Spectrochim Acta Part A Mol Biomol Spectrosc 67(5):1433-1437

Huan X, Tang YG, Xu JJ, Lan CY, Wang SQ (2019) Structural characterization of graphenic material prepared from anthracites of different characteristics: a comparative analysis. Fuel Process Technol 183:8-18

Mao SJ, Cui JJ, Linghu JS, Sun ZM, Chen HZ (2018) System design and key technology of transparent mine management control platform. J China Coal Soc 12:3539-3548

Ren DY, Zhao FH, Wang YQ, Yang SJ (1999) Distributions of minor and trace elements in Chinese coals. Int $\mathrm{J}$ Coal Geol 40(2-3):109-118

Tang YG, Guo YN, Wang SQ (2011) The Chinese typical coal type bark coal: a review. Bull Natl Nat Sci Found China 3:154-163

Tang YG, Wang XS, Schobert HH, Eble CF, Yang CW, Su YF, Ye K, Cao QS, Liu GH (2020) Cleaning potential of selected coals in Shanxi Province, China: evaluation of geological factors affecting the cleaning potential. Energy Fuels 34(2):1396-1407 